\title{
PENERAPAN BIOTEKNOLOGI DALAM EKSTRAKSI MINYAK KELAPA DENGAN MENGGUNAKAN KHAMIR ROTI (Saccharomyces cerevisiae)
}

\author{
Leta (majene@upbjj.mail.ut.ac.id) \\ Universitas Terbuka UPBJJ Majene
}

\begin{abstract}
This research is aimed for knowing the influence of temperature, $\mathrm{pH}$, and their interaction on the amount and quality of oils formed in fermentative extraction of coconut oil using bakers, yeast the treatment examined temperature divided into four treatments, $\mathrm{pH}$ divided into two treatments, and three repetitions. All treatment in this research met SII. The research result show that: (1) Treatment of temperatures give different effects on the amount of oils, temperatures of $35^{\circ} \mathrm{C}$ and $30^{\circ} \mathrm{C}$ produced the highest amount of oil, give different effects on water content, temperatures of $30^{\circ} \mathrm{C}$ and $35^{\circ} \mathrm{C}$ resulted in the lowest amount of water content, gave different effect on iodine number, and on lathering number, temperature of $35^{\circ} \mathrm{C}$ resulted in the lowest number, did not give different effects on the level of free-fats acid. (2) Treatment of $\mathrm{pH}$ did not give different effect on the amount of oil, on water content but give different effect on iodine number, on lathering number, $\mathrm{pH}$ of 4 was lower the $\mathrm{pH}$ of 4.5. (3) Interaction of treatments of temperatures and $\mathrm{pHs}$ give different effect on the amount of oil, temperatures of $35^{\circ} \mathrm{C}$ with $\mathrm{pH}$ of 4 and temperatures of $30^{\circ} \mathrm{C}$ with $\mathrm{pH} 4$ produced highest amount of oil, give different effect on water content, temperature of $30^{\circ} \mathrm{C}$ with the $\mathrm{pH}$ of 4.5 resulted in the lowest amount of water content, the temperature of $25^{\circ} \mathrm{C}$ with $\mathrm{pH} 4.5$ produced high water content $(0.55 \%)$, temperature $30^{\circ} \mathrm{C}$ with $\mathrm{pH} 4.5$ resulted in the lowest peroxide number. It gives different effect on the content of free fats acid, produced oil whit bright colour, good taste and smell and it was not immediately rancid.
\end{abstract}

Key words : biotechnology, coconut oil, fermentation, quality oil, yeast.

Minyak merupakan salah satu komponen bahan pangan yang sangat dibutuhkan manusia, karena fungsinya yang beranekaragam, antara lain sebagai media penggorengan, sebagai salah satu bahan untuk formulasi pangan, pelarut vitamin $A, D, E$, dan $K$, insulator tubuh, sebagai sumber energi yang tertinggi ( $9 \mathrm{kkal} / \mathrm{g}$ ), berperan dalam mengatur tekstur, flavor, dan aroma bahan pangan serta dapat juga memberikan rasa yang gurih terhadap produk pangan (Barlina, 1993).

Ekstraksi dengan rendemen basah dilakukan pertama-tama dengan memarut daging buah kelapa, dilanjutkan dengan menambah air dan pengepresan sehingga diperoleh santan. Tahap selanjutnya adalah pemecahan emulsi santan untuk memisahkan minyak yang biasanya dilakukan dengan cara pemanasan atau krenseng untuk menguapkan air. Suhu yang tinggi menyebabkan protein mengalami denaturasi dan menggumpal menjadi bethak/blondo dan pada akhir pemanasan diperoleh minyak kelapa yang masih mengandung air.

Muchtadi dan Utari (1989), mengemukakan bahwa dengan memperoleh minyak kelapa melalui cara krenseng sangat merugikan, karena ampas kelapa dan "galendo,, atau ",blondho,, masih mengandung minyak sekitar $35.4 \%$. Selain itu, hanya sekitar $50 \%$ minyak yang dapat diekstraksi 
dari daging buah kelapa dan dinilai kurang menguntungkan, karena rendemen minyak yang diperoleh rendah dan banyak bagian buah kelapa yang tidak dimanfaatkan. Selain itu minyak yang dihasilkan berwarna kecoklatan dan mudah menjadi tengik.

Beberapa usaha telah dilakukan untuk mendapatkan minyak kelapa yang berkualitas dan sekaligus residu padatan yang dapat dimanfaatkan untuk dikonsumsi oleh manusia, diantaranya dengan mengekstraksi minyak kelapa secara enzimatis (menggunakan enzim alfa-amilase, bromelin, pektinase, dan selulase), ekstraksi minyak kelapa secara fermentasi dengan menggunakan ragi tape, ragi tempe, dan khamir roti (Muchtadi \& Utari, 1989). Ekstraksi minyak kelapa secara fermentasi dengan menggunakan ragi tape yang telah dilakukan oleh Suhadijono dan Syamsiah (1987), memberikan hasil minyak maksimum dalam waktu fermentasi 24 jam untuk perlakuan 12\% berat ragi dalam stater, $20 \%$ volume stater dalam krim dan suhu fermentasi $40{ }^{\circ} \mathrm{C}$, yaitu $33,45 \%$ dari volume krim mula-mula $(80,73 \%)$. Hal yang sama juga dilakukan oleh Kumalaningsih dan Hidayat (1995) dengan menggunakan ragi tempe dan ragi tape,dimana dalam satu liter santan dengan ragi tempe menghasilkam minyak sebanyak $100,28 \mathrm{~mL}$ dan dengan ragi tape menghasilkan minyak 89,61 $\mathrm{mL}$.

Ekstraksi minyak kelapa dengan menggunakan khamir roti (Saccharimyces cerevisiae) dengan cara rendemen basah yang dimodifikasi telah dilakukan pada praktikum Biologi Terapan Program SI Kedua FPMIPA IKIP Bandung pada jurusan Pendidikan IPA Sekolah Dasar tahun 1994. Cara ekstraksi ini membutuhkan waktu pemanasan yang lebih singkat yaitu 10 - 15 menit, sehingga dapat mengurangi kerusakan minyak kelapa yang dihasilkan, dapat menghemat biaya bahan bakar, minyak yang diperoleh jernih dan baunya tidak tengik. Namun pada saat itu belum ada penelitian dan pengkajian tentang suhu dan $\mathrm{pH}$ yang optimal bagi pertumbuhan khamir roti untuk menghasilkan minyak yang terbanyak dengan kualitas yang baik.

Minyak kelapa hasil fermentasi dengan menggunakan ragi roti merupakan salah satu hasil penerapan bioteknologi yang sederhana karena bahan dasarnya mudah diperoleh dan dapat diterapkan pada masyarakat produsen minyak kelapa, sebagai salah satu contoh penerapan peranan mikroorganiseme (Bioproses) dalam industri pangan. Penelitian ini bertujuan untuk mengetahui pengaruh suhu terhadap jumlah dan kualitas minyak yang terekstrak secara fermentasi, dengan menggunakan khamir roti (Saccharomyces cerevisiae).

\section{METODOLOGI}

Penelitian ini merupakan penelitian eksperimental dalam Rancangan Acak Lengkap (RAL) pola faktorial dengan dua faktor. Faktor pertama yaitu suhu $(T)$ yang terdiri dari empat level/perlakuan yakni $\mathrm{T}_{1}=25^{\circ} \mathrm{C}, \mathrm{T}_{2}=27^{\circ} \mathrm{C}, \mathrm{T}_{3}=30^{\circ} \mathrm{C}, \mathrm{T}_{4}=35^{\circ} \mathrm{C}$. Faktor kedua yaitu keasaman atau $\mathrm{pH}(\mathrm{K})$ yang terdiri dari dua level/perlakuan yakni $\mathrm{K}_{1}=4, \mathrm{~K}_{2}=4,5$. Dengan demikian perlakuan ini terdiri dari $4 \times 2=8$ kombinasi perlakuan. Masing-masing perlakuan diulang sebanyak 3 kali, sehingga diperoleh 24 satuan perlakuan. 
Skema penelitian

\begin{tabular}{lllll}
\hline T1K1 & T2K2 & T3K1 & T4K2 & \\
T1K2 & T2K1 & T3K2 & T4K1 & । \\
\hline T1K1 & T2K1 & T3K2 & T4K1 & II \\
T1K2 & T2K2 & T3K1 & T4K2 & III \\
\hline T4K1 & T3K2 & T2K1 & T1K2 & T1K1 \\
T4K2 & T3K1 & T2K2 & T1K1 & \\
\hline
\end{tabular}

Bahan baku yang digunakan adalah buah kelapa yang cukup kering (kering di pohon) yang tumbuh di daerah pesisir pantai Barane Kabupaten Majene Sulawesi Barat. Penelitian ini dilaksanakan di Laboratorium Biologi Ruang Mikrobiologi Jurusan Biologi FPMIPA Universitas Negeri Malang dan analisis kualitas minyak yang dihasilkan dilakukan di Laboratorium Kimia, Jurusan Kimia Fakultas Matematika dan IImu Pengetahuan Alam Universitas Brawijaya Malang.

Data minyak yang terbentuk diperoleh dengan perhitungan secara persentase yaitu berat minyak yang terbentuk dibagi dengan berat krim santan mula-mula dikalikan dengan seratus persen. Kualitas minyak diperoleh dengan melakukan pengujian menggunakan Standar Industri Indonesia (SII) tentang mutu dan cara uji minyak kelapa dengan indikator yaitu kadar air, bilangan jod, bilangan penyabunan, bilangan peroksida, kadar asam lemak bebas, warna dan bau.

Variabel terikat meliputi jumlah dan kualitas minyak yang terekstrak dari santan kelapa sebagai hasil fermentasi. Data yang diperoleh dianalisis dengan menggunakan Analisis Variansi (ANAVA) ganda dengan 2 faktor. Untuk melihat efek antar tiap level perlakuan dilanjutkan dengan Duncan Multiple Range Test (DMRT = uji jarak berganda Duncan).

\section{HASIL DAN PEMBAHASAN}

Hasil penelitian tentang pengaruh suhu dan pH terhadap jumlah dan kualitas minyak kelapa yang terbentuk secara fermentasi dengan menggunakan khamir roti (Saccharomyces cerevisiae) secara keseluruhan dapat dilihat pada Tabel 1.

\section{Jumlah Minyak yang Terbentuk}

Hasil analisis varian dua jalur untuk jumlah minyak yang terbentuk diperoleh $F$-hitung untuk perlakuan suhu adalah 9,494 dengan nilai $p=0,001$ (lebih kecil dari $\alpha=0,05$ ). Untuk perlakuan keasaman $(\mathrm{pH}$ ) diperoleh $\mathrm{F}$ hitung 2,759 dengan $\mathrm{p}=0,116$ (lebih besar dari $\alpha=0,05$ ). Dengan demikian berdasarkan analisis data tentang pengaruh suhu dan $\mathrm{pH}$ terhadap jumlah minyak yang terbentuk dengan demikian secara fermentasi dengan menggunakan khamir roti diperoleh bahwa perlakuan $\mathrm{pH}$ dan interaksi antara perlakuan suhu dan $\mathrm{pH}$ tidak memberikan pengaruh yang berbeda terhadap jumlah minyak yang terekstrak. Sedangkan perlakuan suhu memberikan pengaruh yang nyata terhadap jumlah minyak yang terekstrak secara fermentasi dengan menggunakan khamir roti. 
Tabel 1. Data Hasil Penelitian Secara Keseluruhan

\begin{tabular}{rrrlrrrrrrr}
\hline N0 & U & T & K & \multicolumn{1}{l}{ Jod } & Sabun & Asam & Perok & Air & Minyak & $\%$ \\
\hline 1 & 1 & 1 & 9,45 & 293,51 & 0,22 & 0,72 & 0,16 & 137,14 & 45,71 & \\
1 & 1 & 2 & 9,17 & 299,50 & 0,15 & 0,51 & 0,67 & 123,51 & 41,17 & \\
3 & 1 & 2 & 1 & 8,79 & 289,10 & 0,18 & 0,40 & 0,42 & 115,46 & 38,49 \\
4 & 1 & 2 & 2 & 9,27 & 293,78 & 0,14 & 0,71 & 0,27 & 120,66 & 40,22 \\
5 & 1 & 3 & 1 & 8,60 & 288,45 & 0,20 & 0,70 & 0,23 & 125,02 & 41,67 \\
6 & 1 & 3 & 2 & 8,90 & 301,58 & 0,14 & 0,70 & 0,02 & 138,65 & 46,22 \\
7 & 1 & 4 & 1 & 9,23 & 278,05 & 0,21 & 0,55 & 0,13 & 150,06 & 50,02 \\
8 & 1 & 4 & 2 & 9,35 & 289,37 & 0,12 & 0,35 & 0,17 & 133,44 & 44,48 \\
9 & 2 & 1 & 1 & 9,34 & 294,37 & 0,19 & 0,70 & 0,20 & 139,76 & 46,59 \\
10 & 2 & 1 & 2 & 9,13 & 287,94 & 0,13 & 0,54 & 0,50 & 114,83 & 38,28 \\
11 & 2 & 2 & 1 & 8,82 & 288,85 & 0,19 & 0,42 & 0,38 & 109,25 & 36,42 \\
12 & 2 & 2 & 2 & 9,24 & 294,65 & 0,11 & 0,70 & 0,24 & 110,84 & 36,95 \\
13 & 2 & 3 & 1 & 8,46 & 287,73 & 0,22 & 0,71 & 0,20 & 148,20 & 49,40 \\
14 & 2 & 3 & 2 & 8,85 & 300,25 & 0,16 & 0,68 & 0,05 & 143,34 & 47,78 \\
15 & 2 & 4 & 1 & 9,15 & 277,65 & 0,18 & 0,51 & 0,16 & 150,80 & 50,27 \\
16 & 2 & 4 & 2 & 9,27 & 288,90 & 0,13 & 0,38 & 0,20 & 140,67 & 46,89 \\
17 & 3 & 1 & 1 & 9,43 & 295,53 & 0,22 & 0,71 & 0,17 & 138,10 & 46,03 \\
18 & 3 & 1 & 2 & 9,11 & 288,82 & 0,14 & 0,54 & 0,48 & 138,43 & 46,14 \\
19 & 3 & 2 & 1 & 8,94 & 288,74 & 0,20 & 0,46 & 0,41 & 123,98 & 41,33 \\
20 & 3 & 2 & 2 & 9,30 & 295,07 & 0,15 & 0,73 & 0,29 & 135,56 & 45,19 \\
21 & 3 & 3 & 1 & 8,56 & 288,93 & 0,24 & 0,70 & 0,25 & 160,59 & 53,53 \\
22 & 3 & 3 & 2 & 8,89 & 300,36 & 0,13 & 0,71 & 0,03 & 143,49 & 47,83 \\
23 & 3 & 4 & 1 & 9,22 & 278,15 & 0,23 & 0,57 & 0,16 & 163,31 & 54,44 \\
24 & 3 & 4 & 2 & 9,40 & 288,94 & 0,15 & 0,36 & 0,19 & 139,08 & 46,36 \\
\hline
\end{tabular}

Keterangan:

U : Ulangan sebanyak 3 kali

$\mathrm{T}$ (Suhu) : Perlakuan suhu terdiri dari: $1=25^{\circ} \mathrm{C} ; 2=27{ }^{\circ} \mathrm{C} ; 3=30{ }^{\circ} \mathrm{C} ; 4=35^{\circ} \mathrm{C}$

$\mathrm{K}(\mathrm{pH}) \quad$ : Perlakuan keasaaman terdiri dari: $1=\mathrm{pH} 4,0 ; 2=\mathrm{pH} 4,5$.

Jod : Kualitas minyak berupa angka Jod (g jod/100g sampel)

Sabun : Kualitas minyak berupa bilangan penyabunan (mg KOH/g sampel)

Asam : Kualitas minyak berupa bilangan asam lemak bebas (\%).

Perok : Kualitas minyak berupa bilangan peroksida (mg oksigen/g sampel)

Air : Kualitas minyak berupa kadar air (\%).

Minyak : Jumlah minyak dalam gram.

$\% \quad$ : Prosentase minyak kelapa yang terbentuk.

Untuk perlakuan keasaman $(\mathrm{pH})$ diperoleh F-hitung 2,758868 dengan nilai $p=0,116183(\mathrm{p}$ lebih besar daripada $a=0,05$ ). Untuk interaksi kombinasi perlakuan suhu dan keasaman diperoleh $F$ hitung 1,702163 dengan nilai $p=0,206680$ ( $p$ lebih besar daripada $\alpha=0,05$ ).

Berdasarkan uji lanjut Duncan rerata jumlah minyak yang terbentuk dari hasil perlakuan suhu terdapat pada Tabel 2. 
Tabel 2. Hasil Uji Duncan Rerata Jumlah Minyak yang Terbentuk untuk Perlakuan Suhu

\begin{tabular}{cll}
\hline Perlakuan Suhu $\left({ }^{\circ} \mathrm{C}\right)$ & Rerata Jumlah Minyak (Gram) & Notasi Duncan \\
\hline $\mathrm{T}_{2}(27)$ & 19,29 & $\mathrm{a}$ \\
$\mathrm{T}_{1}(25)$ & 131,96 & $\mathrm{~b}$ \\
$\mathrm{~T}_{3}(30)$ & 143,22 & $\mathrm{~b} \mathrm{C}$ \\
$\mathrm{T}_{4}(35)$ & 146,23 & $\mathrm{C}$ \\
\hline
\end{tabular}

Keterangan : Rerata yang diikuti dengan notasi huruf sama berarti tidak berbeda nyata. Rerata yang diikuti dengan notasi huruf yang tidak sama berarti berbeda secara nyata.

Tabel 2 menunjukkan rerata jumlah minyak yang terendah adalah perlakuan suhu $27^{\circ} \mathrm{C}$ dan tertinggi adalah perlakuan suhu $35^{\circ} \mathrm{C}$ yaitu 146,2267 gram dari 300 gram krim santan yang dibuat. Perlakuan suhu $35^{\circ} \mathrm{C}$ tidak berbeda nyata dengan perlakuan suhu $30^{\circ} \mathrm{C}$ yang menghasilkan minyak 143,2120 gram.

Pembuatan minyak kelapa dengan proses fermentasi secara basah dimulai dengan pemarutan daging kelapa, sehingga sel-selnya rusak dan isi sel dengan mudah dapat dikeluarkan dalam wujud emulsi putih yang dikenal dengan santan. Penggunaan khamir roti pada emulsi santan dan koagulasi protein yang menyebabkan minyak terpisah dari lemak dan mengendap membentuk galendo.

Fardiaz (1992) menyatakan bahwa suhu optimum pertumbuhan khamir hampir sama dengan suhu optimum pertumbuhan kapang yaitu $25-30^{\circ} \mathrm{C}$ dan suhu maksimum $37-47^{\circ} \mathrm{C}$. Khamir yang hidup pada suhu yang sesuai ini akan menghasilkan enzim protease, lipase, dan amilase. Keberhasilan proses fermentasi itu sendiri antara lain tergantung dari aktivitas enzim yang dipengaruhi oleh banyak sedikitnya substrat, jenis maupun jumlah mikroorganisme penghasil enzim yang bersangkutan (Street, 1983 dan Andayani, 1994 dalam Juani, 1997).

Dengan demikian aktivitas enzim yang dihasilkan oleh khamir tergantung suhu optimum yang digunakan dalam pembuatan minyak. Pernyataan ini telah terbukti dalam penelitian ini. Berdasarkan hasil Anava, nilai F-hitung untuk konsentrasi perlakuan suhu yaitu 9,494 menunjukkan bahwa suhu memberikan pengaruh yang cukup besar terhadap jumlah minyak yang terbentuk.

Pada penelitian ini, pengaruh $\mathrm{pH}$ dan interaksi antara perlakuan suhu dan $\mathrm{pH}$ secara statistik belum memberikan pengaruh yang nyata terhadap jumlah minyak yang terekstrak. Dari segi jumlah minyak yang terekstrak, kombinasi perlakuan suhu $35^{\circ} \mathrm{C}$ dengan $\mathrm{pH} 4,0$ yaitu sebesar 154,72 gram minyak dari setiap 300 gram krim santan atau $51,57 \%$. Selanjutnya diikuti kombinasi perlakuan suhu $30^{\circ} \mathrm{C}$ dengan $\mathrm{pH} 4,0$ yaitu sebesar 144,60 gram $(48,20 \%)$ minyak. Sedangkan yang paling rendah diperoleh dari kombinasi perlakuan suhu $27^{\circ} \mathrm{C}$ dengan $\mathrm{pH} 4,0$ yaitu sebesar 116,23 gram $(38,74 \%)$ minyak.

\section{Kualitas Minyak yang Terbentuk}

Hasil pengujian laboratorium sebagai indikator kualitas minyak yang terbentuk sebagai hasil fermentasi sesuai dengan syarat mutu minyak yang ditetapkan oleh Departemen Perindustrian dalam SII adalah berupa kadar air, bilangan jod, bilangan penyabunan, bilangan peroksida, kadar asam lemak bebas (sebagai asam laurat) serta bau dan warna. 


\section{a. Kadar Air}

Hasil analisis varian dua jalur untuk kualitas minyak diperoleh F-hitung untuk perlakuan suhu terhadap kadar air adalah 47,694 dengan nilai $p=0,000$ (lebih kecil dari $\alpha=0,05$ ). Untuk perlakuan keasaman $(\mathrm{pH}$ ) terhadap kadar air diperoleh F-hitung 1,391 dengan nilai $p=0,255$ ( $p$ lebih besar dari $\alpha=0,05$ ) dan untuk interaksi kombinasi perlakuan suhu dan keasaman terhadap kadar air diperoleh F-hitung 56,573 dengan nilai $p=0,000$ ( $p$ lebih kecil dari $\alpha=0,05$ ). Dengan demikian perlakuan $\mathrm{pH}$ tidak memberikan pengaruh yang berbeda terhadap kadar air dalam minyak. Sedangkan perlakuan suhu dan interaksi antara perlakuan suh dan $\mathrm{pH}$ memberikan pengaruh yang nyata .terhadap kadar air minyak yang terekstrak secara fermentasi dengan menggunakan khamir roti.

Tabel 3. Hasil Uji Duncan Rerata Kadar Air untuk Perlakuan Suhu

\begin{tabular}{ccc}
\hline Perlakuan Suhu $\left({ }^{\circ} \mathrm{C}\right)$ & Rerata Kadar Air $(\%)$ & Nilai Duncan \\
\hline $\mathrm{T}_{3}(30)$ & 0,13 & $\mathrm{a}$ \\
$\mathrm{T}_{4}(35)$ & 0,18 & $\mathrm{a}$ \\
$\mathrm{T}_{2}(27)$ & 0,34 & $\mathrm{~b}$ \\
$\mathrm{~T}_{1}(25)$ & 0,36 & $\mathrm{~b}$ \\
\hline
\end{tabular}

Tabel 4. Hasil Uji Duncan Rerata Kadar Air untuk Interaksi Perlakuan Suhu dengan Keasaman (pH)

\begin{tabular}{|c|c|c|c|}
\hline \multicolumn{2}{|c|}{ Perlakuan } & \multirow[b]{2}{*}{ Rerata Kadar Air (\%) } & \multirow[b]{2}{*}{ Notasi Duncan } \\
\hline Suhu $\left({ }^{\circ} \mathrm{C}\right)$ & $\mathrm{pH}$ & & \\
\hline $\mathrm{T}_{3}(30)$ & $\mathrm{K}_{2}(\mathrm{pH} 4,5)$ & 0,03 & $\mathrm{a}$ \\
\hline $\mathrm{T}_{4}(35)$ & $\mathrm{K}_{1}(\mathrm{pH} 4,0)$ & 0,15 & $b$ \\
\hline $\mathrm{T}_{1}(25)$ & $\mathrm{K}_{1}(\mathrm{pH} 4,0)$ & 0,18 & $b$ \\
\hline $\mathrm{T}_{4}(35)$ & $\mathrm{K}_{2}(\mathrm{pH} 4,5)$ & 0,19 & $b$ \\
\hline $\mathrm{T}_{3}(30)$ & $\mathrm{K}_{1}(\mathrm{pH} 4,0)$ & 0,23 & b c \\
\hline $\mathrm{T}_{2}(27)$ & $\mathrm{K}_{2}(\mathrm{pH} 4,5)$ & 0,27 & C \\
\hline $\mathrm{T}_{2}(27)$ & $\mathrm{K}_{1}(\mathrm{pH} 4,0)$ & 0,40 & $d$ \\
\hline $\mathrm{T}_{1}(25)$ & $\mathrm{K}_{2}(\mathrm{pH} 4,5)$ & 0,55 & $\mathrm{e}$ \\
\hline
\end{tabular}

Keterangan : Rerata yang diikuti dengan notasi huruf sama berarti tidak berbeda nyata. Rerata yang diikuti dengan notasi huruf yang tidak sama berarti berbeda scara nyata.

Berdasarkan hasil rerata kadar air pada perlakuan suhu, $\mathrm{pH}$, dan interaksi, maka kadar air pada semua level perlakuan belum melebihi standar kualitas kadar air yang ditentukan yaitu di bawah 0,5\%. Kombinasi perlakuan suhu $25^{\circ} \mathrm{C}$ dengan $\mathrm{pH} 4,5$ merupakan perlakuan satu-satunya yang melebihi standar dari segi kualitas air $(0,55 \%)$.

\section{b. Bilangan Jod}

Hasil analisis varian dua jalur untuk kualitas minyak kelapa berupa bilangan jod diperoleh Fhitung untuk perlakuan suhu terhadap bilangan jod adalah 142,053 dengan nilai $p=0,000$ (lebih kecil dari $\alpha=0,05)$. Perlakuan keasaman ( $\mathrm{pH}$ ) terhadap bilangan jod diperoleh F-hitung 50,312 dengan nilai $p=0,000$ (lebih kecil dari $\alpha=0,05$ ). Interaksi kombinasi perlakuan suhu dan keasaman terhadap bilangan jod diperoleh F-hitung 48,21 dengan nilai $p=0,000$ ( $p$ lebih kecil dari $\alpha=0,05$ ).

Hasil penelitian ini menunjukkan bahwa perlakuan suhu dapat memberikan pengaruh yang berbeda terhadap bilangan jod minyak yang terekstrak. Berdasarkan hasil rerata bilangan pada 
perlakuan suhu, $\mathrm{pH}$, dan interaksi maka bilangan jod dari semua level perlakuan belum melebihi standar kualitas bilangan jod yang ditentukan yaitu 8-10 g jod/100g sampel (Tabel 5, 6, dan 7).

Tabel 5. Hasil Uji Duncan Rerata Bilangan Jod untuk Perlakuan Suhu

\begin{tabular}{ccc}
\hline $\begin{array}{c}\text { Perlakuan Suhu } \\
\left({ }^{\circ} \mathrm{C}\right)\end{array}$ & $\begin{array}{c}\text { Rerata Bilangan Jod } \\
\text { (gram jod/100gram) }\end{array}$ & Notasi Duncan \\
\hline $\mathrm{T}_{3}(30)$ & 8,71 & $\mathrm{a}$ \\
$\mathrm{T}_{2}(27)$ & 9,06 & $\mathrm{~b}$ \\
$\mathrm{~T}_{4}(35)$ & 9,27 & $\mathrm{C}$ \\
$\mathrm{T}_{1}(25)$ & 9,27 & $\mathrm{C}$ \\
\hline
\end{tabular}

Tabel 6. Hasil Uji Duncan Rerata Bilangan Jod untuk Perlakuan pH

\begin{tabular}{ccc}
\hline $\begin{array}{c}\text { Perlakuan } \mathrm{pH} \\
\text { (gran jod/100 gram ) }\end{array}$ & Rerata Bilangan Jod & Notasi Duncan \\
\hline 4,0 & 8,99 & $\mathrm{a}$ \\
4,5 & 9,15 & $\mathrm{~b}$ \\
\hline
\end{tabular}

Tabel 7. Hasil Uji Duncan Rerata Bilangan Jod untuk Interaksi Perlakuan Suhu dan Keasaman (pH)

\begin{tabular}{|c|c|c|c|}
\hline \multicolumn{2}{|c|}{ Perlakuan } & \multirow{2}{*}{$\begin{array}{l}\text { Rerata Bilangan Jod } \\
\text { (gram jod/100 g) }\end{array}$} & \multirow[t]{2}{*}{ Notasi Duncan } \\
\hline Suhu $\left({ }^{\circ} \mathrm{C}\right)$ & $\mathrm{pH}$ & & \\
\hline $\mathrm{T}_{3}(30)$ & $\mathrm{K}_{1}(\mathrm{pH} 4,0)$ & 8,54 & a \\
\hline $\mathrm{T}_{2}(27)$ & $\mathrm{K}_{1}(\mathrm{pH} 4,0)$ & 8,85 & $b$ \\
\hline $\mathrm{T}_{3}(30)$ & $\mathrm{K}_{2}(\mathrm{pH} 4.5)$ & 8,88 & $b$ \\
\hline $\mathrm{T}_{1}(25)$ & $\mathrm{K}_{2}(\mathrm{pH} 4,5)$ & 9,14 & C \\
\hline $\mathrm{T}_{4}(35)$ & $\mathrm{K}_{1}(\mathrm{pH} 4,0)$ & 9,20 & $c d$ \\
\hline $\mathrm{T}_{2}(27)$ & $\mathrm{K}_{2}(\mathrm{pH} 4,5)$ & 9,27 & $d e$ \\
\hline $\mathrm{T}_{4}(35)$ & $\mathrm{K}_{2}(\mathrm{pH} 4,5)$ & 9,34 & e $f$ \\
\hline $\mathrm{T}_{1}(25)$ & $\mathrm{K}_{1}(\mathrm{pH} 4,0)$ & 9,41 & $f$ \\
\hline
\end{tabular}

Keterangan: Rerata yang diikuti dengan notasi huruf sama berarti tidak berbeda nyata. Rerata yang diikuti dengan notasi huruf sama berarti berbeda secara nyata.

\section{c. Bilangan Penyabunan}

Hasil analisis varian dua jalur untuk kualitas minyak berupa bilangan penyabunan diperoleh F-hitung untuk perlakuan suhu terhadap bilangan penyabunan adalah 26,991 dengan nilai $p=0,000$ (lebih kecil dari $\alpha=0,05)$. Untuk perlakuan keasaman $(\mathrm{pH})$ terhadap bilangan penyabunan diperoleh F- hitung 48,657 dengan nilai $p=0,000$ (lebih kecil dari $\alpha=0,05$ ). Untuk interaksi kombinasi perlakuan suhu dan keasaman terhadap bilangan penyabunan diperoleh F-hitung 12,311 dengan nilai $p=0,000$ ( $p$ lebih kecil dari $\alpha=0,05$ ). Dengan demikian perlakuan suhu, $\mathrm{pH}$, dan interaksi variasi suhu dengan $\mathrm{pH}$ memberikan pengaruh yang nyata terhadap kualitas minyak berupa bilangan penyabunan.

Hasil uji lanjut Duncan untuk perlakuan suhu, keasaman, dan interaksinya terhadap bilangan penyabunan berturut-turut dapat dilihat pada Tabel 8, 9, dan 10. 
Tabel 8. Hasil Uji Duncan Rerata Bilangan Pengabunan untuk Perlakuan suhu

\begin{tabular}{ccc}
\hline $\begin{array}{c}\text { Perlakuan Suhu } \\
\left({ }^{\circ} \mathrm{C}\right)\end{array}$ & $\begin{array}{c}\text { Rerata Bilangan Penyabunan } \\
(\mathrm{mg} \mathrm{KOH} / \mathrm{g})\end{array}$ & Notasi Duncan \\
\hline $\mathrm{T}_{4}(35)$ & 283,51 & $\mathrm{a}$ \\
$\mathrm{T}_{2}(27)$ & 291,70 & $\mathrm{~b}$ \\
$\mathrm{~T}_{1}(25)$ & 293,28 & $\mathrm{~b}$ \\
$\mathrm{~T}_{3}(30)$ & 294,55 & $\mathrm{~b}$ \\
\hline
\end{tabular}

Tabel 9. Hasil Uji Duncan Rerata Bilangan Penyabunan untuk Perlakuan pH

\begin{tabular}{ccc}
\hline Perlakuan pH & $\begin{array}{c}\text { Rerata Bilangan Penyabunan } \\
(\mathrm{mg} \mathrm{KOH} / \mathrm{g})\end{array}$ & Notasi Duncan \\
\hline 4,0 & 278,42 & $\mathrm{a}$ \\
4,5 & 294,10 & $\mathrm{~b}$ \\
\hline
\end{tabular}

Tabel 10. Hasil Uji Duncan Rerata Bilangan Penyabunan untuk Interaksi Perlakuan Suhu dan Keasaman $(\mathrm{pH})$

\begin{tabular}{|c|c|c|c|}
\hline \multicolumn{2}{|c|}{ Perlakuan } & \multirow{2}{*}{$\begin{array}{l}\text { Rerata Bilangan Penyabunan } \\
(\mathrm{mg} \mathrm{KOH} / \mathrm{g})\end{array}$} & \multirow[t]{2}{*}{ Notasi Duncan } \\
\hline Suhu $\left({ }^{\circ} \mathrm{C}\right)$ & Keasaman & & \\
\hline $\mathrm{T}_{4}(35)$ & $\mathrm{pH} 4,0$ & 277,95 & a \\
\hline $\mathrm{T}_{3}(30)$ & $\mathrm{pH} 4,0$ & 288,37 & b \\
\hline $\mathrm{T}_{2}(27)$ & $\mathrm{pH} 4,0$ & 288,90 & b \\
\hline $\mathrm{T}_{4}(35)$ & $\mathrm{pH} 4,5$ & 289,07 & $b$ \\
\hline $\mathrm{T}_{1}(25)$ & $\mathrm{pH} \mathrm{4,5}$ & 292,09 & b c \\
\hline $\mathrm{T}_{1}(25)$ & $\mathrm{pH} 4,0$ & 294,47 & C \\
\hline $\mathrm{T}_{2}(27)$ & $\mathrm{pH} 4,5$ & 294,50 & C \\
\hline $\mathrm{T}_{3}(30)$ & $\mathrm{pH} \mathrm{4,5}$ & 300,73 & $\mathrm{~d}$ \\
\hline
\end{tabular}

Keterangan: Rerata yang diikuti dengan notasi huruf yang sama berarti berbeda nyata. Rerata yang diikuti dengan notasi huruf yang tidak sama berarti berbeda secara nyata.

Berdasarkan hasil rerata bilangan penyabunan pada perlakuan suhu, $\mathrm{pH}$ dan interaksi, maka bilangan penyabunan dari semua level perlakuan melebihi standar kualitas bilangan penyabunan yang ditentukan yaitu 255 - $265 \mathrm{mg} \mathrm{KOH} / \mathrm{g}$ sampel.

\section{d. Bilangan Peroksida}

Hasil analisis varian dua jalur untuk kualitas minyak berupa bilangan peroksida diperoleh $\mathrm{F}$ hitung untuk perlakuan suhu terhadap bilangan peroksida adalah 170,711 dengan nila $p=0,000$ (lebih kecil dari $\alpha=0.05)$. Untuk perlakuan keasaman $(\mathrm{pH})$ terhadap bilangan peroksida diperoleh Fhitung 6,400 dengan nila $p=0,022$ (lebih kecil dari $\alpha=0,05$ ). Untuk interaksi kombinasi perlakuan suhu dan keasaman terhadap bilangan peroksida diperoleh F-hitung 193,896 dengan $p=0,000$ (lebih kecil dari $\alpha=0,05$ ). Hal ini menunjukkan bahwa suhu, keasaman, dan interaksi variasi suhu dengan keasaman berpengaruh terhadap bilangan peroksida.

Hasil uji lanjut Duncan untuk mengetahui adanya perbedaan rerata bilangan peroksida di antara perlakuan suhu, pH dan interaksinya dapat dilihat berturut-turut pada Tabel 11, 12, dan 13. 
Tabel 11. Hasil Uji Duncan Rerata Bilangan Peroksida Perlakuan Suhu

\begin{tabular}{ccc}
\hline $\begin{array}{c}\text { Perlakuan Suhu } \\
\left({ }^{\circ} \mathrm{C}\right)\end{array}$ & $\begin{array}{c}\text { Rerata Bilangan Peroksida } \\
(\mathrm{mg} \text { oksigen/g) }\end{array}$ & Notasi Duncan \\
\hline $\mathrm{T}_{4}(35)$ & 0,45 & $\mathrm{a}$ \\
$\mathrm{T}_{2}(27)$ & 0,57 & $\mathrm{~b}$ \\
$\mathrm{~T}_{1}(25)$ & 0,62 & \multicolumn{2}{c}{$\mathrm{C}$} \\
$\mathrm{T}_{3}(30)$ & 0,70 & $\mathrm{~d}$ \\
\hline
\end{tabular}

Tabel 12. Hasil Uji Duncan Rerata Bilangan Peroksida untuk perlakuan pH

\begin{tabular}{ccc}
\hline Perlakuan pH & $\begin{array}{c}\text { Rerata Bilangan Peroksida } \\
\text { (mg oksigen/g) }\end{array}$ & Notasi Duncan \\
\hline 4,5 & 0,58 & $\mathrm{a}$ \\
4,0 & 0,60 & $\mathrm{~b}$ \\
\hline
\end{tabular}

Tabel 13. Hasil Uji Duncan Rerata Bilangan Peroksida untuk Interaksi Perlakuan Suhu dan Keasaman

\begin{tabular}{|c|c|c|c|}
\hline \multicolumn{2}{|c|}{ Perlakuan } & Rerata Bilangan Peroksida & \multirow[t]{2}{*}{ Notasi Duncan } \\
\hline Suhu $\left({ }^{\circ} \mathrm{C}\right)$ & Keasaman & (mg oksigen/g) & \\
\hline$\overline{T_{4}(35)}$ & $\mathrm{K}_{2}(\mathrm{pH} 4,5)$ & 0,36 & a \\
\hline $\mathrm{T}_{2}(27)$ & $\mathrm{K}_{1}(\mathrm{pH} 4,0)$ & 0,43 & b \\
\hline $\mathrm{T}_{1}(25)$ & $\mathrm{K}_{2}(\mathrm{pH} 4,5)$ & 0,53 & c \\
\hline $\mathrm{T}_{4}(35)$ & $\mathrm{K}_{1}(\mathrm{pH} 4,0)$ & 0,54 & c \\
\hline $\mathrm{T}_{3}(30)$ & $\mathrm{K}_{2}(\mathrm{pH} 4,5)$ & 0,70 & $d$ \\
\hline $\mathrm{T}_{3}(30)$ & $\mathrm{K}_{1}(\mathrm{pH} 4,0)$ & 0,70 & $d$ \\
\hline $\mathrm{T}_{1}(25)$ & $\mathrm{K}_{1}(\mathrm{pH} 4,0)$ & 0,71 & $d$ \\
\hline $\mathrm{T}_{2}(27)$ & $\mathrm{K} 2(\mathrm{pH} 4,5)$ & 0,71 & $d$ \\
\hline
\end{tabular}

Keterangan: Retata yang diikuti dengan notasi huruf sama berarti tidak berbeda nyata. Rerata yang diikuti dengan notasi huruf tidak sama berarti berbeda secara nyata.

Berdasarkan hasil rerata bilangan peroksida pada perlakuan suhu, $\mathrm{pH}$ dan interaksi, maka pada semua level perlakuan memenuhi standar mutu yang telah ditentukan dan bahkan jauh di bawah ambang batas, yaitu di bawah $5,0 \mathrm{mg}$ oksigen/g sampel.

\section{e. Kadar Asam Lemak Bebas}

Hasil analisis varian dua jalur untuk kualitas minyak berupa kadar asam lemak bebas diperoleh F-hitung untuk perlakuan suhu terhadap kadar asam lemak bebas adalah 1,401 dengan nilai $p=0,279$ (lebih besar dari $\alpha=0,05$ ). Untuk perlakuan keasaman $(\mathrm{pH}$ ) terhadap kadar asam lemak bebas diperoleh F-hitung 94,363 dengan nilai $p=0,000$ (lebih kecil dari $\alpha=0,05$ ). Interaksi kombinasi perlakuan suhu dan keasaman terhadap kadar asam lemak bebas diperoleh $\mathrm{F}$-hitung 0,379 dengan nilai $p=0,769$ (lebih besar dari $\alpha=0,05$ ). Dengan demikian perlakuan suhu dan interaksi variasi suhu dengan keasaman $(\mathrm{pH})$ tidak memberikan pengaruh yang berbeda terhadap kadar asam lemak bebas, sedangkan perlakuan suhu berpengaruh nyata.

Untuk mengetahui perbedaan di antara perlakuan $\mathrm{pH}$ terhadap kadar asam lemak bebas, dilakukan uji Duncan hasilnya tertera pada Tabel 14. 
Tabel 14. Hasil Uji Duncan Rerata Kadar Asam Lemak Bebas untuk Perlakuan Keasaman (pH).

\begin{tabular}{ccc}
\hline Perlakuan $\mathrm{pH}$ & Rerata Kadar Asam Lemak bebas (\%) & Notasi Duncan \\
\hline 4,5 & 0,14 & $\mathrm{a}$ \\
4,0 & 0,21 & $\mathrm{~b}$ \\
\hline
\end{tabular}

Kadar asam lemak bebas dari minyak yang terekstrak didasarkan atas perhitungan asam laurat. Rerata kadar asam lemak bebas yang diperoleh pada penelitian ini masih memenuhi standar kualitas kadar asam lemak bebas yang ditentukan bahkan jauh di bawah ambang batas yaitu di bawah $5 \%$.

\section{f. Warna dan Bau}

Dari hasil penelitian secara umum minyak yang dihasilkan telah tersimpan selama lima bulan (September 2000 sampai Januari 2001), warna dan baunya masih normal yaitu warnanya jernih seperti semula dan baunya belum ada tanda-tanda akan mengalami ketengikan. Hal ini membuktikan bahwa minyak yang dihasilkan dengan cara fermentasi dengan menggunakan khamir roti (Saccharomyces cerevisiae) mempunyai daya simpan yang lebih lama dibandingkan dengan cara konvensional (minyak kelentik).

Dari hasil laboratorium indikator kualitas minyak yang terbentuk sebagai hasil fermentasi sesuai dengan syarat mutu yang ditentukan oleh Departemen Perindustrian dapat diketahui bahwa semua indikator masih memenuhi persyaratan atau tidak melebihi ambang batas, kecuali bilangan penyabunan. Indikator-indikator tersebut adalah bilangan jod, bilangan peroksida, kadar asam lemak bebas serta warna dan bau. Untuk indikator kadar air, perlakuan yang tidak memenuhi persyaratan adalah kombinasi perlakuan suhu $25^{\circ} \mathrm{C}$ dengan $\mathrm{pH} 4,5$. Kombinasi perlakuan ini mempunyai kadar air $0,55 \%$ yang berarti lebih tinggi daripada persyaratan yang ditentukan yaitu $0,5 \%$. Untuk indikator bilangan penyabunan, semua level perlakuan berada di atas rentangan standar mutu minyak goreng yaitu di atas $265 \mathrm{mg} \mathrm{KOH} / \mathrm{g}$ sampel.

Bila dikaji secara keseluruhan indikator termasuk jumlah minyak yang terekstrak, maka kombinasi perlakuan suhu $35^{\circ} \mathrm{C}$ dengan $\mathrm{pH} 4,0$ dan kombinasi perlakuan suhu $30^{\circ} \mathrm{C}$ dengan $\mathrm{pH} 4,0$ merupakan kombinasi perlakuan yang disarankan dilakukan untuk menghasilkan jumlah minyak dengan kualitas yang baik hasil minyak berturut-turut mencapai 51,57 dan 48,20\%. Indikator lain yaitu bilangan jod, bilangan peroksida, kadar asam lemak bebas (sebagai asam laurat) masih di bawah ambang batas persyaratan. Untuk bilangan penyabunan juga diperoleh hasil yang paling rendah yaitu kombinasi perlakuan $35^{\circ} \mathrm{C}$ dan $\mathrm{pH} 4,0$ mencapai $277,9500 \mathrm{mg} \mathrm{KOH} / \mathrm{g}$ dan perlakuan suhu $30^{\circ} \mathrm{C}$ dan $\mathrm{pH} 4,0$ mencapai $288,3700 \mathrm{mg} \mathrm{KOH} / \mathrm{g}$ sampel. Jika angka penyabunan ini dibandingkan dengan batas persyaratan $265 \mathrm{mg} \mathrm{KOH} / \mathrm{g}$ sampel, relatif tidak jauh perbedaannya.

\section{KESIMPULAN DAN SARAN}

\section{Kesimpulan}

Berdasarkan hasil analisis data dalam penelitian ini, maka dapat ditarik kesimpulan sebagai berikut:

1. Perlakuan suhu memberikan pengaruh yang berbeda terhadap jumlah minyak yang diekstrak dengan suhu $35^{\circ} \mathrm{C}$ dan $30^{\circ} \mathrm{C}$ menghasilkan jumlah minyak yang tertinggi. Perlakuan suhu memberikan pengaruh yang berbeda terhadap kadar air, bilangan jod, bilangan penyabunan, 
bilangan peroksida dan tidak memberikan pengaruh yang berbeda terhadap kadar asam lemak bebas dari minyak yang terekstrak. Semua perlakuan suhu menghasilkan minyak yang masih memenuhi standar kualitas yang dipersyaratkan, kecuali indikator bilangan penyabunan di atas ambang batas standar kualitas.

2. Perlakuan $\mathrm{pH}$ tidak memberikan pengaruh yang berbeda terhadap jumlah minyak yang terekstrak. Untuk kualitas minyak, perlakuan $\mathrm{pH}$ tidak memberikan pengaruh yang berbeda terhadap kadar air minyak yang terekstrak. Perlakuan $\mathrm{pH}$ memberikan pengaruh yang berbeda terhadap bilangan jod, bilangan penyabunan, bilangan peroksida, dan kadar asam lemak bebas dari minyak yang terekstrak. Semua perlakuan $\mathrm{pH}$ menghasilkan kualitas minyak yang masih memenuhi standar yang dipersyaratkan.

3. Interaksi perlakuan suhu dengan $\mathrm{pH}$ tidak memberikan pengaruh yang berbeda terhadap jumlah minyak dan kadar asam lemak bebas. Interaksi perlakuan suhu dengan $\mathrm{pH}$ memberikan pengaruh yang berbeda terhadap kadar air, bilangan jod, bilangan penyabunan, bilangan peroksida dari minyak yang terekstrak. Hanya perlakuan suhu $25^{\circ} \mathrm{C}$ dengan $\mathrm{pH} 4,5$ menghasilkan kadar air di atas standar kualitas yaitu 0,55\% dan semua interaksi perlakuan suhu dengan $\mathrm{pH}$ menghasilkan bilangan penyabunan di atas ambang batas standar kualitas. Interaksi perlakuan suhu dengan $\mathrm{pH}$ menghasilkan minyak yang berwarna jernih dan baunya harum bahkan tidak mudah mengalami proses ketengikan.

\section{Saran}

Berdasarkan hasil penelitian ini, maka dapat diberikan beberapa saran sebagai berikut :

1. Bila ingin membuat minyak kelapa dengan cara fermentasi dengan menggunakan khamir roti (Saccharomyces cerevisiae), agar dihasilkan minyak yang tertinggi dan memenuhi standar kualitas yang dipersyaratkan oleh Standar Industri Indonesia (SII 0150-72), hendaknya digunakan kombinasi suhu $35^{\circ} \mathrm{C}$ dengan $\mathrm{pH} 4,0$ dan kombinasi suhu $30^{\circ} \mathrm{C}$ dengan $\mathrm{pH} 4,0$.

2. Dalam penelitian ini tidak dilakukan penggunaan variabel bebas macam kultivar atau varietas kelapa, tempat tumbuhnya pohon kelapa, dan uji organoleptik terhadap warna dan bau dan disarankan dilakukan penelitian lebih lanjut tentang hal tersebut terhadap jumlah dan kualitas minyak yang terekstrak.

\section{REFERENSI}

Barlina, R. (1993). Kontroversi isu minyak tropis. Buletin Balitka, (20), 1 - 12.

Fardiaz, S. (1992). Mikrobiologi pangan I. Kerja Sama PAU Pangan dan Qizi IPB Jakarta: PT Gramedia.

Juani, M. (1997). Pengaruh suhu pada pembuatan kultur khamir (Candida utilis) Dalam pengembangan tepung jagung terhadap aktivitas enzim protease. Skripsi yang tidak dipublikasikan. FMIPA Universitas Brawijaya Malang.

Kumalaningsi, S., \& Hidayat, N. (1995). Mikrobiologi hasil pertanian. Malang: IKIP Malang.

Muchtadi, D. \& Utari, N. (1989). Pengolahan buah kelapa secara enzimatis dan evaluasi minyak serta nilai qizi protein yang dihasilkan. Prosiding Seminar Nasional Hasil Penelitian Perguruan Tinggi, 21-24 Januari 1991. Dirjen Dikti Depdikbud.

Standar Industri Indonesia Nomor 0150-72 tentang mutu dan cara uji minyak Kelapa. (1972). Jakarta: Departemen Perindutrian RI.

Suhadijono \& Syamsiah, S. (1987). Pembuatan minyak kelapa dengan cara Fermentasi. PAU Pangan dan Qizi UGM. Yogyakarta: Liberty. 